\title{
TOPOGRAPHY AND SURFACE DEPOSITS OF PART OF SASKATCHEWAN IN RELATION TO THE RECESSION OF THE PLEISTOCENE ICE SHEET
}

by the late F. H. Edmunds, * Department of Geological Sciences, University of Saskatchewan

In travelling across the Saskatchewan plains one soon becomes convinced of the extreme youthfulness of the topography. There are a few deep valleys such as those of the North and South branches of the Saskatchewan River; there are a few tributaries such as Eagle Hill Creek and Swift Current Creek, which have their valleys extending back for many miles from the main rivers. Here and there, there are deep valley channels or trenches that are either dry or have. a series of lakes in their beds or have streams too small, by far, to have been responsible for the cutting of such valleys. Notable examples of channels of this kind are Blackstrap Coulee, the Watrous Lake channel and the Qu'Appelle valley. Apart from these valley features, the country is a plain, in places rolling, in places almost level. The drainage is poorly developed except for narrow strips of and adjacent to the main valleys.
Another feature which impresses itself upon the traveller is that over a majority of the area the land is stony with a plentiful supply of erratic boulders which are either crystalline gneisses and schists of Precambrian age or limestone rocks of Palaeozoic age. These boulders have been carried south and distributed over the Plains by the ice of the Pleistocene glaciation. The topographic features of these glacial drift areas are varied; in some places they are on relatively high land and the terrain is rough and rolling with a typical "knob and kettle" physiography, in other places it is but gently rolling and in places almost smooth. It may be observed, also, that there are areas, not inconsiderable in extent, which are stone free and almost level. The surface material may be heavy sticky clay, a silt, and less commonly, a sand. Where sands occur they have usually been drifted by the wind and modified

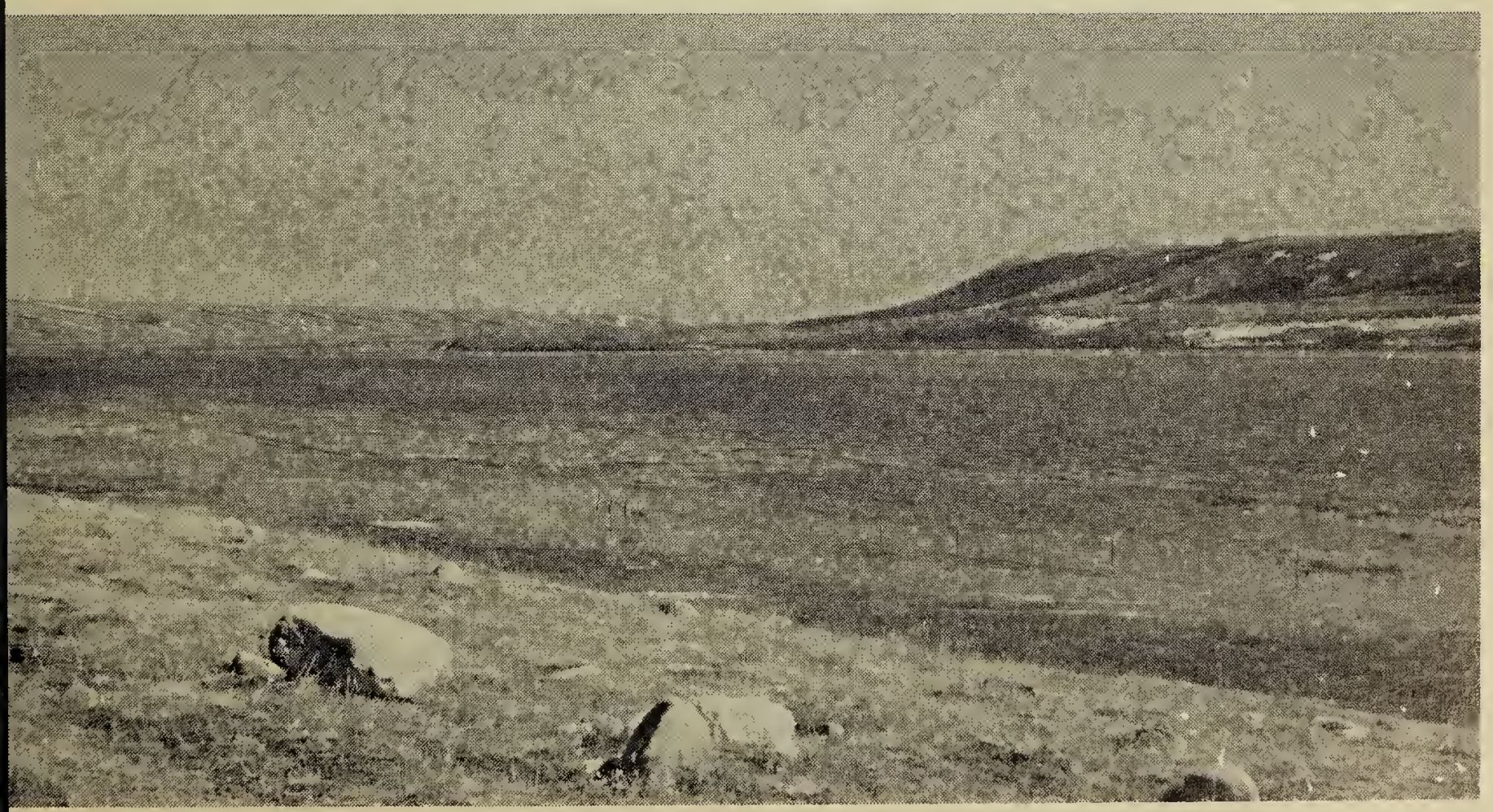

Blackstrap Coulee, April, 1965

Photo by Earl A. Christianser

The manuscript of the following paper by the late Professor F. H. Edmunds was received before his death on February 28, 1965 and is based on his publication listed in the literature Cited (1962). 
Vol. XXIII, No. 2

into sand dunes. The fact that the surface deposits in these stone-free areas are of lake origin becomes apparent when they are examined in detail and in reference to the topographic maps. It is found that the upper limit in elevation of these deposits conforms closely with a definite contour line.

A glance at the soils map (Mitchell, Moss, and Clayton, 1947) will show the variations in the surface materials and their topographic expression. A closer inspection of the soils map in relation to the topographic maps of the province (Topographic sheets of the Sectional Map of Western Canada on a scale of 1 inch to 3 miles, with 50-foot contours, published by the Canada Department of Mines and Technical Surveys, Surveys and Mapping Branch, Ottawa) will show how the lake deposits conform, in general, to the lower areas and the glacial till deposits to the higher areas, but will fail to explain the relationships of the deposits - why, for example, the hoight of lake deposits in the Regina area is approximately 1950 feet above sea level, in the Rosetown area, 2050 feet, in the Elstow area, 1850 feet, in the Saskatoon area, about 1700 feet. Nor will it explain the origin of the now water-deserted old drainage valleys. To explain these features, it is necessary to consider the conditions existing in Saskatchewan at the time the ice was waning.

A barrier of ice to the north profoundly modified the drainage, forcing the melt-water from the ice and ather drainage to find some outlet to the south; in other words, against the natural slope of the land. This resulted in foodings of certain areas to a height corresponding to the elevation of the lowest part of the local drainage divide. The ice barrier was not static but was gradually shifting, either advancing due to accumulation of snow at certain centres of the ice sheet, or melting back because the replenishment of ice at the centres was not able to keep up with the rate of melting at the margin. During the ice age as a whole, there were many fluctuations of the ice sheets but it is not our purpose to discuss them here but rather to consider the last, and, to us, final disappearance of the ice. 1t was during this last recession that the unmistakable and unmodified lake deposits were formed and that the clearly defined drainage channels were eroded.

\section{Ice Front during Recession}

As has been indicated above, the waning of the ice sheets was due to an unfavorable balance in precipitation of snow at the ice centres or over the sheet as a whole, as compared with melting at the margins. It can be assumed that climatic changes were slow and that for the most part, accumulation of ice continued at the centres and that there was continuous movement out from these centres, even though the edges were melting back. The shape and conformation of the ice fronts would be modified profoundly by the major features of the land topography, pushing out in lobes where there was relatively low land and forming re-entrants where there were features that could hold up and deflect the forward movement of the ice.

\section{Recession of the Ice from \\ Part of Saskatchewan}

An attempt has been made to work out the phases in the recession of the last ice sheet from that part of Saskatchewan shown on the maps. The area possesses some major topographic features; the Eagle Hills and the Missouri Coteau are upland areas on the west; the Allan Hills lie near the centre and the Touchwood Hills on the east. Between these higher lands are the South Saskatchewan River lowland and the Last Mountain Lake lowland. By close study of the surface deposits and the topographic features, it has been possible to work out phases in the recession of the ice. These phases have been designated by names of glacial lakes which were in existence at the time (see table next page).

Three of these phases are illustrated to show the most outstanding features of the drainage.

Figure 1, the Late Lake Regina or Lake Rosetown phase, shows the main drainage from Lake Rosetown by way of the Anerley channel to Lake Regina. The South Saskatchewan River also drained into Lake Regina which had its overflow to the southeast by way of the Souris valley. At this phase the Qu'Appelle valley was starting on the east side of the area but in the next phase (Lake Milden), the ice 
melted back from the lower land in which the Qu'Appelle valley is situated, and this became the drainage way for Lake Regina until that lake had disappeared.

In the Early Lake Elstow phase (Figure 2), there were two distinct lobes of ice with a pronounced reentrant to the north of the Allan Hills. The drainage of the South Sas- katchewan River was to the east through the Qu'Appelle valley. Water which accumulated at the ice front in the Saskatchewan River lowland (Lake Swanson) also had its overflow through the Qu'Appelle valley. The Elstow area occupying the re-entrant between the ice lobes was flooded and found its outlet by Last Mountain Lake into the Qu'Appelle, while on



Swift Current Creek valley

Saskatchewan Government Photographic Services

\section{PHASES OF ICE RECESSSION}

Phase

Lake Saskatoon

Late Lake Elstow (Figure 3)

Early Lake Elstow (Figure 2)

Lake Milden

Late Lake Regina (Figure 1)

Early Lake Regina

\section{Drainage}

North by Wakaw channel

East by Watrous and Last Mountain Lake channels to the Qu'Appelle Valley

From Saskatchewan lowland by the Qu'Appelle valley. From Lake Elstow by Lewis and Lasit Mountain Lake channels.

East iby the Qu'Appelle valley

From Lake Rosetown by Anerley channel to Lake Regina

East by Thunder Creek to Lake Regina. 

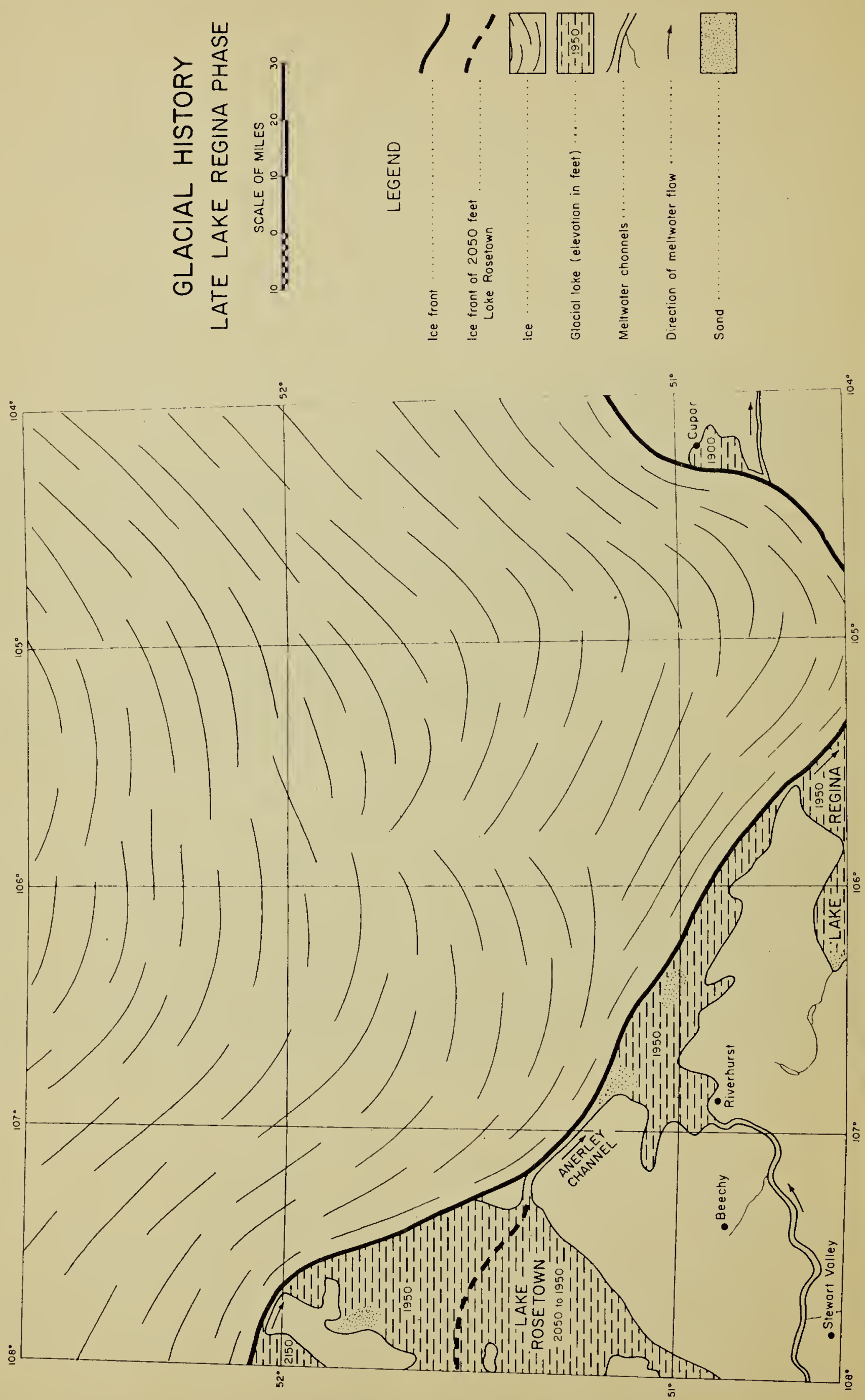


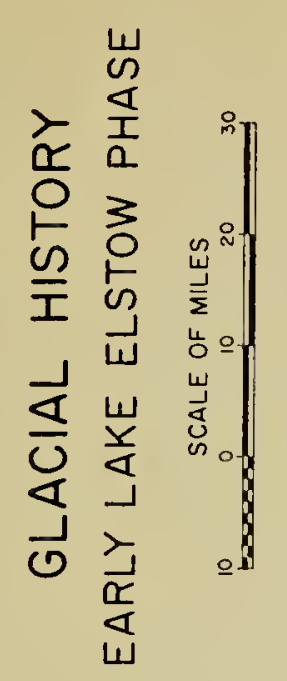

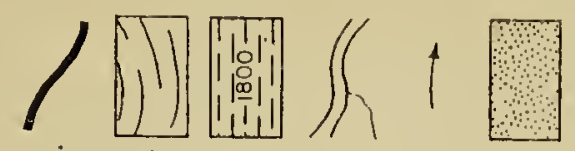
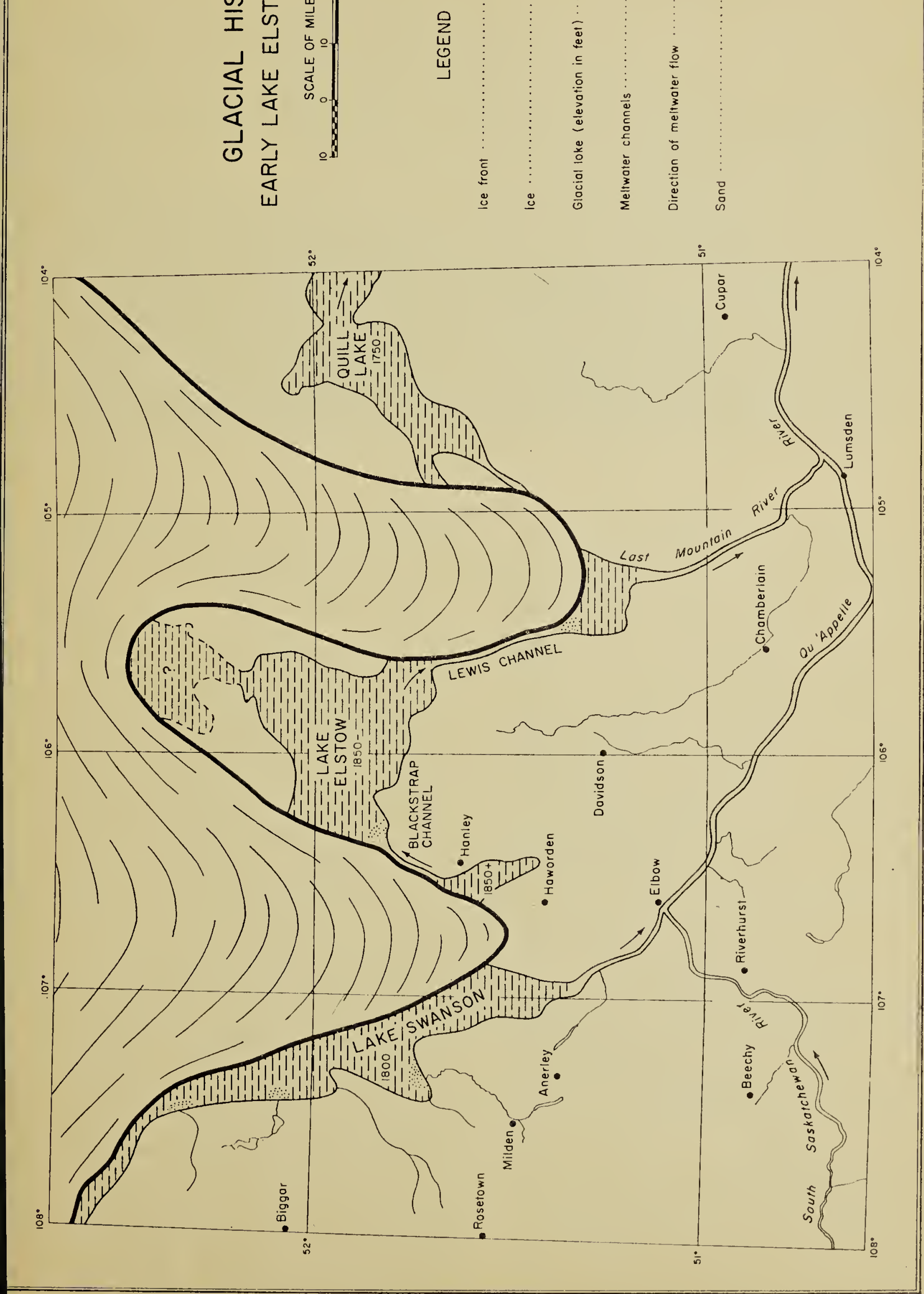


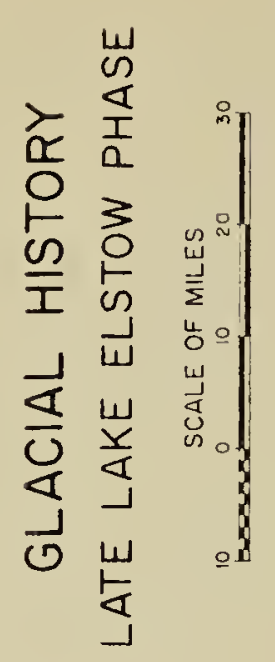

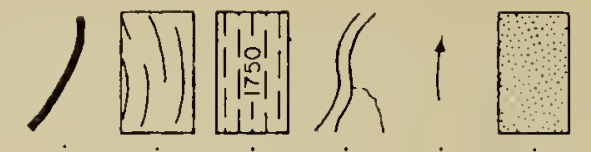
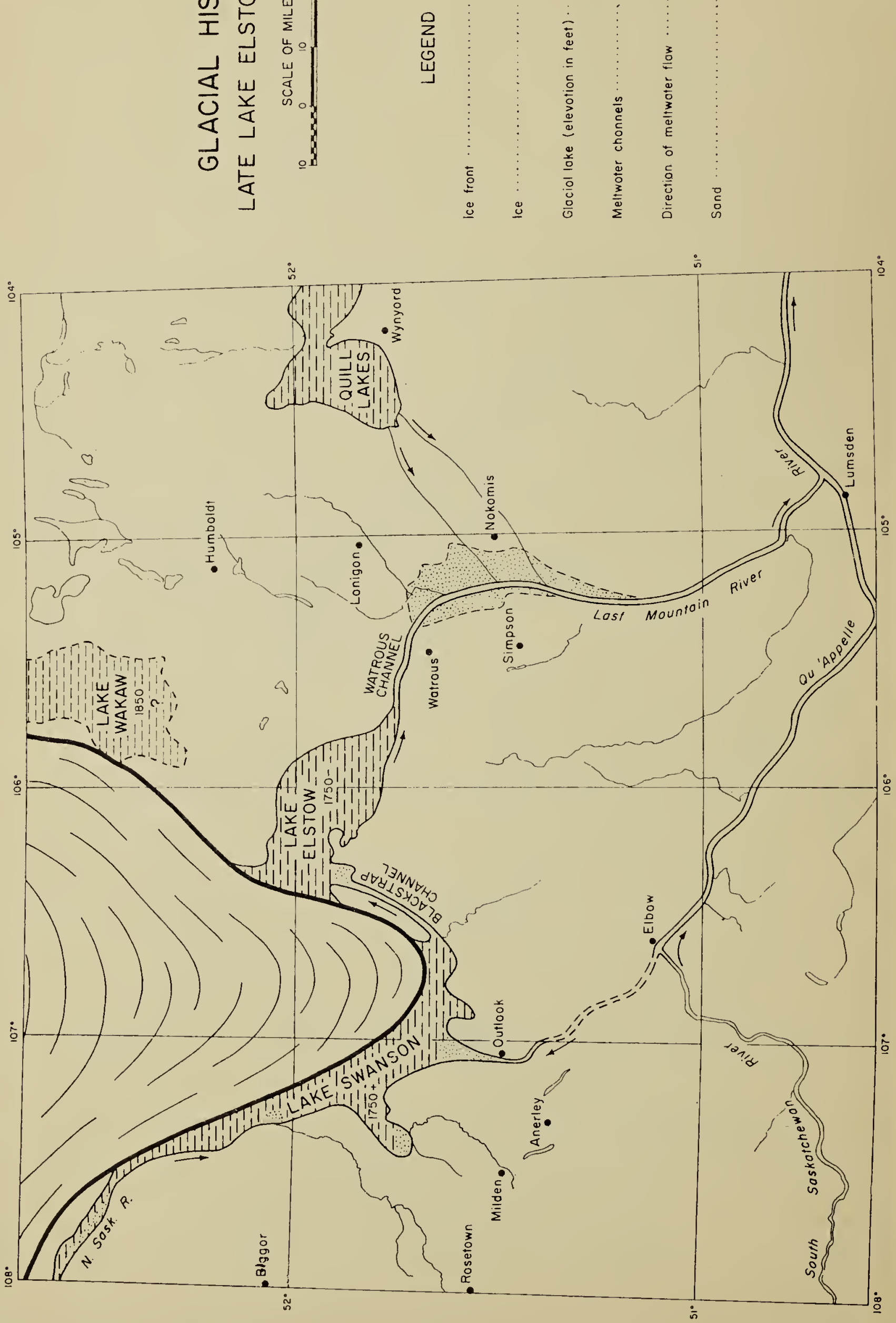


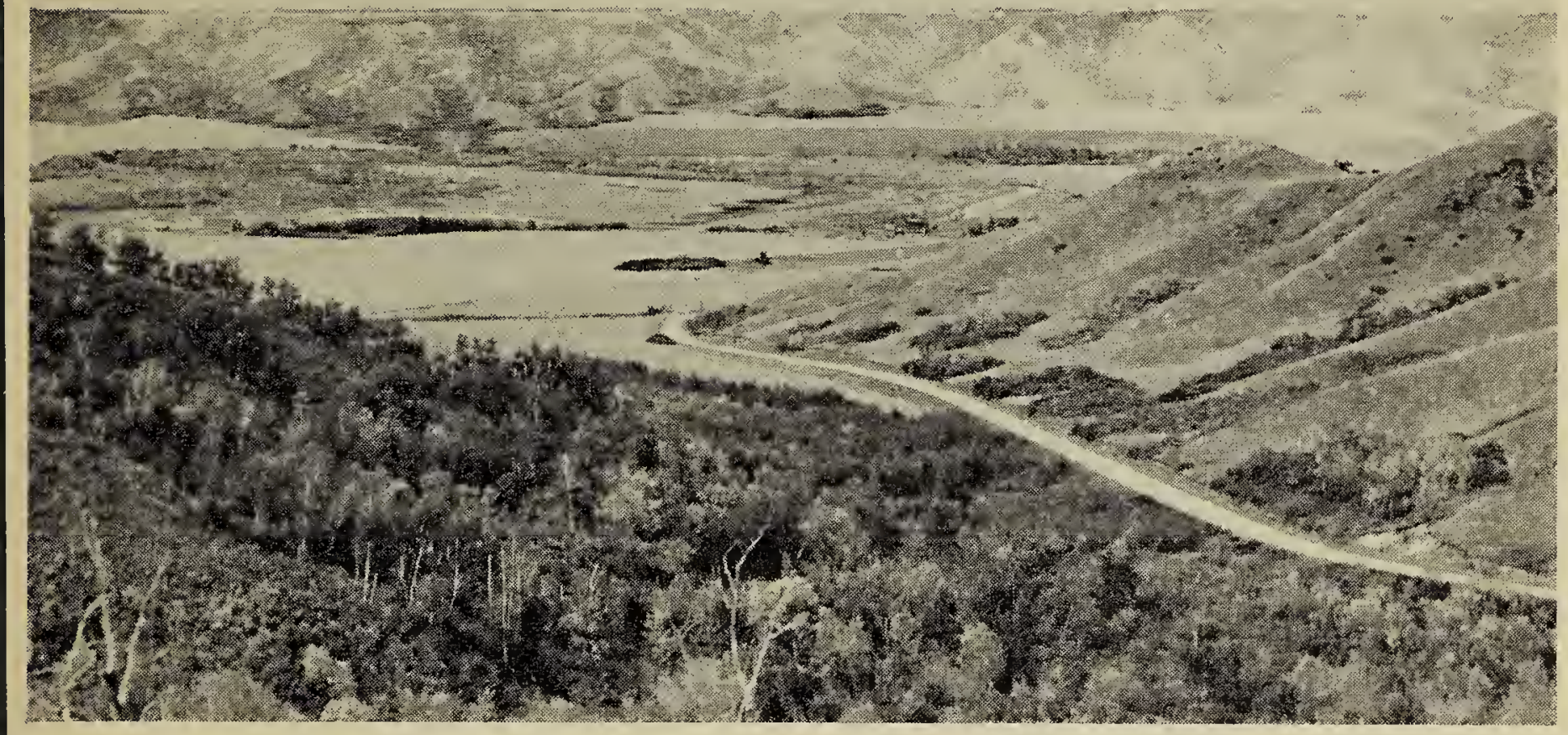

Qu'Appelle Valley north of Grenfell

Sask. Govt. Photographic Services

the east side of the area, the Quill Lakes drained east by the Whitesand River.

By the Late Lake Elstow phase (Figure 3 ) the eastern ice lobe had washed away and a different course for the drainage was established. The South Saskatchewan still flowed through the Qu'Appelle Valley. The reach of the spillway of Lake Swanson between Outlook and The Elbow became temporarily dry. Lake Swanson drained through Blackstrap Channel into Lake Elstow which, by this time, could drain through the Watrous Channel into Last Mountain Lake and so to the Lower Qu'Appelle Valley. Later, during the Lake Saskatoon phase, headward erosion and ultimate tapping by a stream flowing northwesterly in the former outlet valley of Lake Swanson, diverted the South Saskatchewan River at The Elbow northwestward, its present course.

The above features of the glacial drainage in Saskatchewan have been worked out by using the information of the soils and topographic maps. However, before such information was available, similar conclusions with regard to the drainage had already been deduced. Henry Youle Hind (1859) in 1857 was the first to conclude that the South branch of the Saskatchewan River had followed a course from Elbow into the Qu'Appelle valley. In 1890, Warren Upham (1890), who investigated the glacial lake areas of Manitoba, recognized that the Qu'Appelle had formed an outlet for waters of the lake he called Lake Saskatchewan. He also considered that other outlets might have existed and suggested a possible drainage by way of Last Mountain Lake. Upham's Lake Saskatchewan cannot have existed as such but represents the area occupied by Lakes Rosetown, Milden, Swanson, and Saskatoon; lakes which occurred in succession as the ice receded.

\section{LITERATURE CITED}

Edmunds, F. H. 1962. Recession of Wisconsinan glacier from Central Saskatchewan. Sask. Dept. Mineral Resources Report No. 67, 23 p.

Hind, H. Y. 1859. Northwest Territory. Reports of progress together with a preliminary and general report of the Assiniboine and Saskatchewan exploring expedition. Toronto, 201 p.

Mitchell, J., H. C. Moss, and J. S. Clayton. 1947. Soil survey of southern Saskatchewan from township 1 to 48 inclusive. University of Sask., Sask. Soil Survey Report 12 (second ed.).

Upham, W. 1890. Exploration of the glacial Lake Agassiz in Manitoba. Geol. Survey Canada Ann. Report (New Series), Vol, 4, 1888-1889. Report E. 156 p. 